\title{
TATA CARA PENYELESAIAN SENGKETA PEMUTUSAN HUBUNGAN KERJA OLEH PEKERJA BERDASARKAN UNDANG-UNDANG NO. 13 TAHUN 2003 TENTANG KETENAGAKERJAAN*
}

\author{
Oleh \\ I Nyoman Satya Wicaksana** \\ I Ketut Markeling, SH., $\mathrm{MH}^{* * *}$ \\ Bagian Hukum Bisnis \\ Fakultas Hukum Universitas Udayana
}

\begin{abstract}
ABSTRAK
Perjanjian Kerja adalah perjanjian antara seorang "pekerja" dengan seorang "majikan", perjanjian mana ditandai oleh ciri-ciri adanya suatu upah atau gaji tertentu yang diperjanjikan dan adanya suatu hubungan di peratas yaitu suatu hubungan berdasarkan mana pihak yang satu (majikan) berhak memberikan perintah-perintah yang harus ditaati oleh pihak yang lainnya. Tujuan dari penulisan ini untuk mengetahui apa akibat hukumnya bagi pekerja yang melanggar ketentuan perjanjian kerja dan bagaimana cara penyelesaian perselisihan terhadap pelanggaran perjanjian kerja.

Metode yang digunakan didalam penulisan jurnal ini adalah metode penelitian hukum normatif dengan pendekatan perundang-undangan (The Statute Approach) artinya pendekatan yang dilakukan dengan menelah semua undang-undang dan regulasi yang bersangkut-paut sesuai hukum yang ditangani. Hasil dari penelitian ini adalah akibat hukumnya bagi pekerja

*Penulisan karya ilmiah ini berjudul Tata Cara Penyelesaian Sengketa Perjanjian Kerja Berdasarkan Undang-Undang No. 13 Tahun 2003 Tentang Ketenagakerjaan, yang bukan merupakan ringkasan skripsi.

** Penulis pertama dalam penulisan ini ditulis oleh I Nyoman Satya Wicaksana selaku mahasiswa Fakultas Hukum Universitas Udayana

email : satyawik@gmail.com

${ }^{* * *}$ Penulis kedua dalam penulisan ini ditulis oleh I Ketut Markeling, S.H., M.H. selaku Pembimbing Akademik penulis kedua di Fakultas Hukum Universitas Udayana
\end{abstract}


yang melanggar ketentuan perjanjian kerja pekerja wajib membayar ganti rugi sebesar sisa perjanjian kerja dikali gaji setiap bulannya. Dan bagaimana cara penyelesaian perselisihan terhadap pelanggaran perjanjian kerja menurut Undang-Undang Nomor 13 Tahun 2003 adalah tata cara penyelesaian perselisihan terhadap pelanggaran perjanjian kerja yang dilakukan oleh pekerja dapat menempuh jalur di luar pengadilan hubungan industrial (non litigasi) dan dapat juga menempuh di jalur pengadilan hubungan industrial (litigasi).

\title{
Kata Kunci : Perselisihan, Perjanjian Kerja, Pekerja
}

\begin{abstract}
Labor disputes are between employer (employer) and employer (employers) association with trade union or trade union association (unions) due to the non-conformity of union concerning working conditions, work conditions and/or labor conditions. If a labor problem arises, the principal point that must be held firmly is that in resolving labor disputes wherever possible not to terminate the employment relationship. In an enterprise there is an employment agreement in which each worker working within that company must abide by the agreement.

If the employment agreement is terminated before the employment agreement after the worker is obliged to indemnify the employer.The research method used for this research is the normative research method with a legislative approach and a legal analysis approach. The results of this study are the legal consequensce for workers who violate the provisions of the employment agreement, workers must compensate for the rest of the work agreement multiplied by the monthly salary. And how to settle disputes over violations of work agreements according to law no. 13 of 2003 is the procedure for resolving disputes over violations of employment agreements carried out by workers can the the path in an industrial relations court (non litigation) and can also take the path of industrial relations court (litigation)
\end{abstract}

\section{Keyword : Dispute, Employement agreements, Workers}




\section{PENDAHULUAN}

\subsection{Latar Belakang}

Salah satu hal penting yang diatur di dalam UndangUndang No.13 Tentang Ketenagakerjaan adalah mengenai Perjanjian Kerja. Sebelum memulai sebuah pekerjaan dalam sebuah hubungan kerja, pekerja dan pengusaha terlebih dahulu harus membuat sebuah kesepakatan terlebih dahulu yang mengatur mengenai hak dan kewajiban para pihak. Perjanjian tersebut disebut dengan per- janjian kerja. Perjanjian Kerja adalah perjanjian antara seorang "pekerja" dengan seorang "majikan", perjanjian mana ditandai oleh ciri-ciri; adanya suatu upah atau gaji tertentu yang diperjanjikan dan adanya suatu hubungan di peratas yaitu suatu hubungan berdasarkan mana pihak yang satu (majikan) berhak memberikan perintah-perintah yang harus ditaati oleh pihak yang lainnya. ${ }^{1}$

Perjanjian kerja yang akan mengatur mengenai hak dan kewajiban parap pihak serta akan mengatur system kerja yang akan dilakukan oleh pekerja berdasarkan syarat-syarat kerja beserta dengan hak yang akan diterima oleh pekerja sebagai pihak penerima kerja. Keberadaan atau eksistensi dari hukum sebagaimana Cicero pernah mengatakan "ubi societas ibi ius", di mana ada masyarakat di situ ada hukum sangat penting karena hukum dalam tugas utamanya untuk menciptakan ketertiban dalam kehidupan masyarakat, juga sebagai sarana penunjang terhadap hak manu- sia agar tidak dilanggar oleh manusia

${ }^{1}$ Adrian Sutedi, 2009, Hukum Perburuhan, Sinar Grafika, Jakarta, h. 46. 
lainnya. ${ }^{2}$ Indikasi sebuah sistim kerja yang baik akan tercermin dari bagaimana isi dari perjanjian kerja yang disepakati oleh para pihak. Hal ini merupakan perwujudan dari pemenuhan kebutuhan manusia secara baik. ${ }^{3}$

Menurut Pasal 1 angka 14 Undang-Undang No. 13 Tahun 2003 Tentang Ketenagakerjaan memberikan pengertian, "Perjanjian kerja adalah suatu perjanjian antara pekerja dan pengusaha atau pemberi kerja yang memuat syarat-syarat kerja hak dan kewajiban kedua belah pihak". Perjanjian kerja timbul karena adanya suatu persetujuan antara pekerja disatu pihak dengan pengusaha dipihak lain. Perjanjian itu menetapkan antaralain bahwa pekerja akan sanggup melakukan pekerjaan atau tugas yang diperintahkan padanya yang dapat menghasilkan barang atau jasa dengan satu kompensasi dari pengusaha atau pemberi kerja berupa upah yang besarnya tidak kurang dari upah minimum yang berlaku pada saat perjanjian tersebuat dibuat.

Perjanjian timbul karena adanya kesepakatan kedua belah pihak, kesepakatan kedua belah pihak tersebut harus memenuhi syarat-syarat sahnya perjanjian. Menurut Pasal 52 ayat 1 Undang-Undang No.13 Tahun 2003 Tentang Ketenagakerjaan syarat-syarat sahnya suatu perjanjian kerja Antara lain:

1. Adanya kesepakatan antara kedua belah pihak, jadi tidak ada unsur paksaan (tidak ada dwang paksaan, dwaling penyesatan atau kekhilafan atau bedrog penipuan) dalam

2 I Wayan Agus Vijayantera, 2016," Pengaturan Tunjangan Hari Raya Keagamaan Sebagai Hak Pekerja Setelah Di Terbitkan Peraturan Menteri", Kertha Patrika, Vol.38 No.31, Januari 2016, hal.4

https://ojs.unud.ac.id/index.php/kerthapatrika/article/download/30091/1846 3

${ }^{3}$ Cristoforus Valentino Alexander Putra, 2017, "Urgensi Klausula Definisi Dalam Perjanjian Kerja”, Kertha Patrika, Vol.39 No. 01, April 2017, hal. 62 https://ojs.unud.ac.id/index.php/kerthapatrika/article/view/32709 
perjanjian kerja baik fisik maupun phsikologi Tapi pada kenyataanya sering terjadi penyimpangan yang dilakukan oleh pihak perusahaan dengan menetapkan syarat-syarat secara sepihak yang pada intinya akan memaksa pekerja untuk menandatangani perjanjian kerja agar bisa diterima bekerja.

2. Adanya kemampuan atau kecakapan melakukan perbuatan hokum.

3. Adanya pekerjaan tertentu yang telah diperjanjikan, pekerjaan sebagi obyek dalam perjanjian kerja Obyek perjanjian (pekerjaan) harus halal yakni tidak bertentangan dengan Undang-undang, ketertiban umum, kesusilaan. Pekerjaan sebagai syarat sahnya perjanjian, maka pekerjaan itu haruslah ada dan apabila tidak ada, maka perjanjian itu batal demi hukum.

4. Pekerjaan yang diperjanjikan tidak boleh bertentangan dengan ketertiban umum, kesusilaan dan ketentuan peraturan perundang-undangan yang berlaku (Pasal 52 ayat (1) Undang-Undang Ketenagakerjaan). Perjanjian kerja yang tidak ada obyeknya atau yang dilarang oleh peraturan perundang-undangan adalah batal demi hukum (nietig).

Keempat syarat di atas bersifat kumulatif, maksudnya adalah keempat syarat tersebut haruslah dipenuhi semuanya baru dapat dikatakan sebagai perjanjian kerja yang sah. Pekerja dengan perusahaan berada dalam hubungan kemitraan sehingga keduanya dituntut untuk berbagi tanggung jawab. ${ }^{4}$ Penafsiran terhadap perjanjian kerja haruslah dipahami bersama-sama antara pekerja dengan pengusaha secara menyeluruh guna menghindari perselisihan yang terjadi dikemu- dian hari. Dalam

${ }^{4}$ Janus Sidabalok, 2012, Hukum Perusahaan, Nuansa Aulia, Bandung, h.,196. 
membuat dan menyepakati perjanjian kerja, diharapkan para pihak teru- tama pemberi kerja (pengusaha) yang telah membuat kontrak kerja standar menjelaskan secara rinci hak dan kewajiban kedua belah pihak guna meminimalisir terjadinya perbedaan penafsiran dan perselisihan terhadap hak dan kewajiban yang ditimbulkan dari perjanjian kerja tersebut.

\subsection{Rumusan Masalah}

1. Apa Akibat Hukumnya Bagi Pekerja Yang Memutus Hubungan Kerja Dari Perjanjian Kerja Yang Telah Di Tentukan.

2. Bagaimana Cara Penyelesaian Perselisihan Terhadap Pelanggaran Perjanjian Kerja.

\subsection{Tujuan Penulisan}

Tujuan penulisan ini adalah untuk mengetahui apa akibat hukumnya bagi pekerja yang melanggar ketentuan perjanjian kerja dan bagaimana cara penyelesaian perselisihan terhadap pelanggaran perjanjian kerja industrial.

\section{ISI MAKALAH}

\subsection{Metode Penulisan}

Metode yang digunakan didalam penulisan makalah ini adalah metode penelitian hukum normatif dengan pendekatan perundang-undangan (The Statute Approach) artinya pendekatan yang dilakukan dengan menelah semua undang-undang dan regulasi yang bersangkut-paut sesuai hukum yang ditangani. ${ }^{5}$ Bahan hukum diperoleh melalui bahan hukum yang telah diteliti

5 Peter Mahmud Marzuki, 2010, Penelitian Hukum, Cetakan Keenam, Kencana Prenada Media Group, Jakarta, hal. 93. 
dan selanjutnya akan dikumpulkan yang berkaitan dengan permasalahan penelitian ini untuk dilakukan pembahasan. ${ }^{6}$

\subsection{Hasil dan Pembahasan}

\subsubsection{Apa Akibat Hukumnya Bagi Pekerja Yang Memutus Hubungan Kerja Dari Perjanjian Kerja Yang Telah Ditentukan}

Di dalam melakukan sebuah pekerjaan, tentunya terdapat hubungan kerja antara pekerja dan pengusaha, dimana hubungan kerja tersebut dituangkan ke dalam suatu bentuk perjanjian atau kontrak kerja.di dalam perjanjian kerja tersebut memuat apa saja yang menjadi hak dan kewajiban para pekerja dan pengusahanya seperti pendapatan upah/ gaji dan keselamatan kerja. Menurut Pasal 1 angaka 15 Undang-Undang No. 13 tahun 2003 Tentang Ketenagakerjaan, unsur-unsur hubungan kerja terdiri atas adanya pekerjaan, adanya perintah, dan adanya upah.

Perlindungan hukum memberikan pengayoman kepada hak asasi manusia yang dirugikan orang lain dan perlindungan tersebut diberikan kepada masyarakat agar mereka dapat menikmati semua hak-hak yang diberikan oleh hukum. Perlindungan hukum diartikan sebagai suatu bentuk tindakan atau perbuatan hukum pemerintah yang diberikan kepada subjek hukum sesuai dengan hak dan kewajibannya yang dilaksanakan berdasarkan hukum positif di Indonesia.Perlindungan hukum timbul karena adanya suatu hubungan hukum.Hubungan hukum adalah interaksi antara subjek hukum yang memiliki relevansi

${ }^{6}$ Bambang Sunggono, 2010, Metodologi Penelitian Hukum, Rajawali Pers, Jakarta, hal.86 . 
hukum atau mempunyai akibat hukum (timbulnya hak dan kewajiban). ${ }^{7}$

Pemutusan Hubungan Kerja (PHK) adalah salah satu hal dalam dunia ketenagakerjaan yang paling dihindari dan tidak diinginkan oleh para pekerja yang masih aktif bekerja. Untuk masalah pemutusan hubungan kerja yang terjadi sebab berakhirnya waktu yang telah ditetapkan dalam perjanjian kerja tidak menimbulkan permasalahan terhadap kedua belah pihak yaitu pekerja dan pengusaha karena antara pihak yang bersangkutan sama-sama telah menyadari atau mengetahiu saat berakhirnya hubungan kerja tersebut sehingga masing-masing telah berupaya mempersiapkan diri menghadapi kenyataan tersebut.

Berbeda halnya dengan masalah pemutusan hubungan kerja yang terjadi secara sepihak yaitu oleh pihak pekerja, hal tersebut dikarenakan setiap pihak yang diputuskan hubungan kerjanya akan merasa dirugikan, karena perusahaan harus segera mencari pengganti dari pekerja tersebut, untuk mencari seorang pekerja membutuhkan waktu yang cukup lama untuk menyesuaikan keadaan perusahaan, sedangkan disisi lain perusahaan harus terus tetap berjalan demi kelancaran ekonomi perusahaan.

akibat hukum adalah akibat suatu tindakan yang dilakukan untuk memperoleh suatu akibat yang dikehendaki oleh pelaku dan yang diatur oleh hukum Tindakan yang dilakukan merupakan tindakan hukum yakni tindakan yng dilakukan guna memperoleh

7 Abdusalam, 2009, Hukum Ketenagakerjaan, Edisi Revisi, Restu Agung, Jakarta, hal. 27. 
sesuatu akibat yang dikehendaki hokum. ${ }^{8}$ Jika dalam suatu pekerjaan buruh melakukan sebuah pelanggaran kontrak kerja, maka pekerja/buruh berhak untuk mengganti rugi kepada pihak pengusaha seperti yang dinyatakan pada Pasal 62 Undang-Undang No. 13 tahun 2003 Tentang Ketenagakerjaan "Apabila salah satu pihak mengakhiri hubungan kerja sebelum berakhirnya jangka waktu yang ditetapkan dalam perjanjian kerja waktu tertentu, atau berakhirnya hubungan kerja bukan karena ketentuan sebagaimana dimaksud dalam Pasal 61 ayat (1), pihak yang mengakhiri hubungan kerja diwajibkan membayar ganti rugi kepada pihak lainnya sebesar upah pekerja/buruh sampai batas waktu berakhirnya jangka waktu perjanjian kerja.

\subsubsection{Bagaimana Cara Penyelesaian Perselisihan Terhadap Pelanggaran Perjanjian Kerja}

Perselisihan perburuhan ialah pertentangan antar majikan (pengusaha) atau perkumpulan majikan (organisasi pengusaha) dengan serikat buruh atau gabungan serikat buruh (gabungan serikat pekerja) berhubung dengan tidak adanya persesuaian pendapat mengenai hubungan kerja, syarat-syarat kerja dan/ atau keadaan perburuhan.

Dalam sebuah perusahaan, baik itu pengusaha maupun pekerja pada dasarnya memiliki kepentingan atas kelangsungan usaha dan keberhasilan perusahaan. Meskipun keduanya memiliki kepentingan terhadap keberhasilan perusahaan, tidak dapat dipungkiri konflik/perselisihan masih sering terjadi antara pengusaha dan pekerja. hal.295.

8 R Soeroso, 2006, Pengantar Imu Hukum, Sinar Graika, Jakarta, 
Bila sampai terjadi perselisihan antara pekerja dan pengusaha, perundingan bipartit bisa menjadi solusi utama agar mencapai hubungan industrial yang harmonis. Hubungan industrial yang kondusif antara pengusaha dan pekerja menjadi kunci utama untuk menghindari terjadinya Pemutusan Hubungan Kerja, meningkatkan kesejahteraan pekerja serta memperluas kesempatan kerja baru untuk menanggulangi pengangguran di Indonesia

Demikian pula dapat diketahui bahwa perselisihan hubungan meliputi hal-hal sebagai berikut.

1. Perselisihan Hak, yaitu perselisihan yang timbul karena tidak terpenuhinya hak.

2. Perselisahan kepentingan, yaitu perselisihan yang timbul dalam hubungan kerja karena tidak adanya persesuaian pendapat.

3. Perselisihan pemutusan hubungan kerja, yaitu perselisihan yang timbul karena tidak adanya kesesuaian pendapat mengenai pengakhiran hubungan kerja yang dilakukan oleh satu pihak.

4. Perselisihan antara serikat pekerja dalam satu perusahaan, yaitu perselisihan antara pekerja dengan pekerja lain dalam satu perusahaan.

\section{PENYELESAIAN PERSELISIHAN PERBURUHAN DI LUAR JALUR PENGADILAN HUBUNGAN INDUTRIAL}

Setiap perselisihan hubungan wajib diupayakan penyelesaiannya terlebih dahulu melalui perundingan Biparti dan jika perundingan mencapai hasil dibuatkan persetujuan bersama (PB) dan apabila tidak mencapai kesepakatan maka dilakukan upaya Bipartit, Mediasi, Konsiliasi, dan Arbitrase. 


\section{Penyelesaian Melalui Bipartit}

Ketentuan Pasal 6 dan Pasal 7 Undang-Undang No. 2 tahun 2004 memberi jalan penyelesaian sekengketa pekerja dan tenaga kerja berdasarkan musyawarah mufakat dengan mengadakan asas kekeluargaan antar buruh dengan majikan. Apabila terdapat kesepakatan antara pekerja dengan majikan, dapat dituangkan dalam perjanjian kesepakatan kedua belah pihak yang disebut perjanjian bersama.

\section{Penyelesaian Melalui Mediasi}

Perselisihan melalui mediasi hubungan industrial (mediasi) adalah penyelesaian perselisihan hubungan industrial melalui musyawarah yang ditengahi oleh seorang atau lebih mediator yang netral.Perselisahan hubungan industrial yang dapat diselesaikan melalui mediasi adalah Perselisihan hak, Perselisihan kepentingan, Persilisihan pemutusan hubungan kerja, dan Perselisihan antar serikat pekerja/buruh dalam satu perusahaan.

\section{Penyelesaian Melalui Konsiliasi}

Konsiliasi adalah penyelesaian perselisihan hubungan industrial melalui musyawarah yang ditengahi oleh seorang atau lebih konsiliator yang netral. Jenis-jenis perselisihan industrial yang dapat diselesaikan melalui konsiliasi adalah:

a. Perselisihan kepentingan,

b. Perselisihan pemutusan hubungan kerja, dan

c. Perselisihan atar serikat pekerja/buruh dalam suatu perusahaan. 
Dalam hal tidak tersampainya kesepakatan penyelesian melalui konsiliasi, konsiliator mengeluarkan anjuran tertulis dalam waktu selambat-lambatnya 10 hari kerja sejak sidang konsiliasi pertama kepada para pihak.

4. Penyelesaian Melalui Arbitrase

Arbitrase adalah penyelesaian atau pemutusan sengketa oleh seorang hakim atau para hakim yang bertujuan mereka akan tunduk kepada atau menaati keputusan yang telah diberikan oleh hakim atau para hakim yang mereka pilih atau tunjuk tersebut. ${ }^{9}$

\section{PENYELESAIAN PERSELISIHAN PERBURUHAN MELALUi JALUR PENGADILAN}

Jika dengan cara tersebut permasalahan tidak dapat terselesaikan maka para pihak dapat mengajukan gugatan ke pengadilan hubungan industrial.Penyelesaian perselisihan di tingkat Pengadilan Hubungan Industrial selambat-lambatnya 50 hari terhitung sejak siding pertama dilakukan. Hukum acara yang dipakai untuk mengadili sengketa perbutuhan tersebut adalaha Hukum Acara Perdata yang berlaku di lingkungan Pengadilan Umum, kecuali diatur secara khusus oleh Undang-Undang No. 2 Tahun 2004 tentang penyelesaian perselisihan hubungan industrial. Hukum Acara dalam menyelesaikan perselisihan perburuhan. Selanjutnya mengenai proses Beracara Penyeleasaian Perselisihan Perburuhan Pengadilan Hubungan Industrial adalah:

Pengajuan Gugatan

Pemeriksaan di Pengadilan Hubungan Industrial

1. Pemeriksaan dengan Acara Biasa

\footnotetext{
9 Erman Rajagukguk, 2000, Arbitrase dan Putusan Pengadilan, Chandra Pratama, Jakarta, hal. 14.
} 
2. Pemeriksaan dengan Acara Cepat

3. Putusan Pengadilan

\section{PENUTUP}

\subsection{KESIMPULAN}

Berdasarkan hasil penelitian sebagaimana di uraikan dalam bab-bab sebelumnya, sehingga dapat disimpulkan seperti dibawah ini:

1. Pengakhiran perjanjian kerja yang dilakukan secara sepihak oleh pekerja dikenakan ganti rugi sebesar sisa perjanjian kerja kali jumlah gaji yang diterima setiap bulannya.

2. Tata cara penyelesaian perselisihan terhadap pelanggaran perjanjian kerja yang dilakukan oleh pekerja dapat menempuh jalur di luar pengadilan hubungan industrial dan dapat juga menempuh di jalur pengadilan hubungan industrial.

\subsection{SARAN}

1. Dilihat dari kedudukan pekerja yang sangat lemah pengusaha perlu memperhatikan keadaan yang dialami pekerja walaupun undang-undang memberikan hak untuk menuntut ganti rugi kepada pekerja tapi pengusaha mestinya memperhatikan mangkirnya tenaga kerja bukan disebabkan oleh iktikad buruk dari pekerja.

2. Walaupun dalam musyawarah dan hasil putusan pengadilan telah mencapai kesepakatan tersebut mungkin saja di hasilkan karena tekanan dari pihak pengusaha yang lebih kuat, semestinya di harapkan dalam penyelesaian yang serupa dapat dicapai hasil yang seadil-adilnya agra menguntungkan kedua belah pihak. 


\section{DAFTAR PUSTAKA}

\section{Buku :}

Abdusalam, 2009, Hukum Ketenagakerjaan, Edisi Revisi, Restu Agung, Jakarta, hal. 27.

Adrian Sutedi, 2009, Hukum Perburuhan, Sinar Grafika, Jakarta, hal. 46.

Bambang Sunggono, 2010, Metodologi Penelitian Hukum, Rajawali Pers, Jakarta, hal.86

Erman Rajagukguk, 2000, Arbitrase dan Putusan Pengadilan, Chandra Pratama, Jakarta, hal. 14.

Janus Sidabalok, 2012, Hukum Perusahaan, Nuansa Aulia, Bandung, hal.196.

Peter Mahmud Marzuki, 2010, Penelitian Hukum, Cetakan Keenam, Kencana Prenada Media Group, Jakarta, hal. 93.

R Soeroso, 2006, Pengantar Ilmu Hukum, Sinar Graika, Jakarta, hal.295.

\section{Jurnal :}

I Wayan Agus Vijayantera, 2016," Pengaturan Tunjangan Hari Raya Keagamaan Sebagai Hak Pekerja Setelah Di Terbitkan Peraturan Menteri”, Kertha Patrika, Vol.38 No.31, Januari 2016, hal.4

https://ojs.unud.ac.id/index.php/kerthapatrika/article/download /30091/18463

Cristoforus Valentino Alexander Putra, 2017, "Urgensi Klausula Definisi Dalam Perjanjian Kerja”, Kertha Patrika, Vol.39 No. 01, April 2017, hal. 62 
https://ojs.unud.ac.id/index.php/kerthapatrika/article/view/327 09

\section{PERATURAN PERUNDANG-UNDANGAN}

Indonesia, Undang- Undang Dasar Negara Republik Indonesia Tahun 1945

Indonesia, Undang-Undang Nomor 13 Tahun 2003 Tentang Ketenagakerjaan, Lembaran Negara Republik Indonesia Nomor 4279, Lembaran Negara Republik Indonesia Tahun 2003.

Indonesia, Undang-Undang Nomor 2 Tahun 2004 tentang penyelesaian perselisihan hubungan industrial. 